\title{
Single-particle chemical force microscopy to characterize virus surface chemistry
}

Xue Mi' ${ }^{1}$ \& \& Caryn L Heldt*,1 (iD)

${ }^{1}$ Department of Chemical Engineering, Michigan Technological University, Houghton, MI 49931, USA; *Author for correspondence: heldt@mtu.edu

BioTechniques 69: 00-00 (November 2020) 10.2144/btn-2020-0085

First draft submitted: 10 June 2020; Accepted for publication: 20 August 2020; Published online: 1 October 2020

\section{ABSTRACT}

Two important viral surface characteristics are the hydrophobicity and surface charge, which determine the viral colloidal behavior and mobility. Chemical force microscopy allows the detection of viral surface chemistry in liquid samples with small amounts of virus sample. This singleparticle method requires the functionalization of an atomic force microscope (AFM) probe and covalent bonding of viruses to a surface. A hydrophobic methyl-modified AFM probe was used to study the viral surface hydrophobicity, and an AFM probe terminated with either negatively charged carboxyl acid or positively charged quaternary amine was used to study the viral surface charge. With an understanding of viral surface properties, the way in which viruses interact with the environment can be better predicted.

\section{METHOD SUMMARY}

We developed a chemical force microscopy technique with a simple probe functionalization method using thiol attachment and an optimized covalent virus immobilization method. The novel method was used to detect the surface charge and hydrophobicity of viral capsids at a singleparticle level.

KEYWORDS:

atomic force microscopy $\bullet$ BVDV • functionalized AFM tip • PPV • viral capsid characterization • virus immobilization

Virus surface chemistry, primarily the hydrophobicity and surface charge, determines its mobility and governs its colloidal behavior in virus adsorption processes [1,2]. Both the viral hydrophobicity and surface charge can dominate virus removal [3-5] and purification [6] performance in different solutions and influence viral persistence in the environment [7]. However, there is limited information on the viral surface chemistry [8-11]. Current methods for characterizing virus surface chemistry include hydrophobic interaction chromatography [10], zeta potential [12], and isoelectric focusing [13]. The disadvantages of these methods are that many require large amounts of virus, and the cost of production and purification of a large quantity of virus is high. Also, these methods are affected by the purity of virus samples [14] and solution conditions [1,12] and cannot account for heterogeneity in the viral population [15]. Hence, there is a need for methods that can accurately target single viral particles and simultaneously measure the surface chemistry of the virus with a small amount of samples.

A novel surface characterization method, chemical force microscopy (CFM), which uses chemical interactions between a functionalized atomic force microscope (AFM) tip and a sample, is leading to a renewed look at single-particle virus surface chemistry [9]. The chemical interaction is measured by the deflection of the AFM cantilever during the AFM tip approach and withdrawal [16]. The deflection can be converted into the force needed to pull the functionalized AFM tip from the sample using the spring constant of the cantilever and Hooke's law [17]. The AFM probe pull-off force during withdrawal from the sample can be quantified as a measurement of adhesion force $[16,17]$ and can be used to compare the surface chemistry of samples $[9,18-21]$.

CFM is a versatile tool to evaluate the surface chemistry of soft biological material. CFM has been reported to map hydrophobic properties of Mycobacterium abscessus with a hydrophobic methyl $\left(\mathrm{CH}_{3}\right)$-functionalized AFM tip [18] and measure the hydrophobic forces between a Candida glabrata-modified AFM tip and a $\mathrm{CH}_{3}$-modified substrate [19]. A carboxylic acid (COOH)-modified AFM probe has been reported to determine the surface charge of a single Saccharomyces cerevisiae cell surface [21] and the isoelectric points (pls) of porcine parvovirus (PPV) and bovine viral diarrhea virus (BVDV) [9]. The pls of proteins were measured by a protein-functionalized AFM probe and a charged substrate [20]. One key advantage of CFM is that the virus can be studied in a physiological environment without disturbing the natural state of the virus [22]. CFM can measure chemical interactions ranging from strong covalent bonds $(\sim 100 \mathrm{nN})$ to weak van der Waal forces $(\sim 1 \mathrm{pN})[16,23]$, making it a suitable tool for measurement of hydrophobic and electrostatic interactions of viral particles. 
In this report, we describe a single-particle technique CFM to measure virus surface chemistry with small viral samples. The methods of virus immobilization and AFM probe functionalization were explored first. CFM with a $\mathrm{CH}_{3}$-terminated probe was used to study the surface hydrophobicity of a virus, and CFM with a charged probe was used to study the surface charge of a virus.

\section{Materials \& methods}

Virus

PPV and BVDV were purified using a previously established method with dialysis and a desalting column [24]. The buffer for purification was either phosphate-buffered saline (PBS) ( $\mathrm{pH} \mathrm{7.2)} \mathrm{(for} \mathrm{the} \mathrm{hydrophobicity} \mathrm{study)} \mathrm{or} 20 \mathrm{mM}$ phosphate buffer (PB) ( $\mathrm{pH} 7.0$ ) (for the surface charge study). The concentrations of purified virus solutions were titrated to be $1 \times 10^{8} \mathrm{MTT}_{50} / \mathrm{ml}^{\text {for }} \mathrm{PPV}$ and $1 \times 10^{7} \mathrm{MTT} 50 / \mathrm{ml}$ for BVDV using an MTT assay $[9,25]$. Materials sources are detailed in the supplementary information.

\section{Virus samples \& control surfaces preparation}

A diced glass slide (surface area $2.5 \mathrm{~cm}^{2}$ ) was coated with $5 \mathrm{~nm}$ of chromium followed by a 30-nm gold (Au) layer using a Perkin-Elmer Randex Sputtering System (Model 2400; Perkin Elmer, MA, USA). All deposition steps were performed under a $5 \times 10^{-6}$ Torr vacuum. The Au-coated slide was immersed in $14 \mathrm{ml}$ of a mixed solution containing a total of $2 \mathrm{mM}$ of 12 -mercaptododecanoic acid $\left(\mathrm{HS}\left(\mathrm{CH}_{2}\right)_{11} \mathrm{COOH}\right)$ and 1-dodecanethiol $\left(\mathrm{HS}\left(\mathrm{CH}_{2}\right)_{11} \mathrm{CH}_{3}\right)$ in ethanol for $12 \mathrm{~h}$. Then the slide was rinsed with ethanol and air-dried in a chemical hood. The ratio of $\mathrm{COOH}$ - and $\mathrm{CH}_{3}$-capped thiols was 1:1, unless stated otherwise. The functionalized surface was equilibrated with $14 \mathrm{ml}$ Nanopure water for $15 \mathrm{~min}$. The surface was further treated with a total of $0.5 \mathrm{ml}$ of an equal volume mixture of $0.1 \mathrm{M} \mathrm{N}$-hydroxysulfosuccinimide (NHS) and 0.4M 1-ethyl-3-(3-dimethylaminopropyl) carbodiimide hydrochloride (EDC) for 30 min and equilibrated with PBS for 2 min. This step was to activate the $\mathrm{COOH}$ groups to NHS esters. After activation, $0.5 \mathrm{ml}$ of virus surrogate primary amine-functionalized silica nanoparticles ( $\mathrm{NH}_{2}-\mathrm{NPS}$ ) or purified PPV or BVDV was applied to the surface for $30 \mathrm{~min}$. Finally, the surface was washed with Nanopure water three-times and stored in $14 \mathrm{ml}$ of either PBS or PB at $4^{\circ} \mathrm{C}$, depending on whether hydrophobicity or charge, respectively, were to be measured. The control surfaces were prepared in the same manner, except that one pure thiol compound was used.

\section{AFM probe modification}

For hydrophobicity measurements, Au-coated AC-40 AFM probes (spring constant $\sim 0.1 \mathrm{~N} / \mathrm{m}$, tip radius $\sim 10$ nm; Bruker, CA, USA) were immersed in a $14 \mathrm{ml}$ ethanol containing $4 \mathrm{mM}$ of $\mathrm{HS}\left(\mathrm{CH}_{2}\right)_{11} \mathrm{CH}_{3}$ for $24 \mathrm{~h}$, rinsed with ethanol and air-dried in a chemical hood. For surface charge measurement, negatively charged AFM probes were prepared by immersing the AC-40 AFM probes in the same manner in $\mathrm{HS}\left(\mathrm{CH}_{2}\right)_{11} \mathrm{COOH}$. Similarly, positively charged AFM probes were modified by incubating the NT-MDT CSG10/Au AFM probes (spring constant $\sim 0.11 \mathrm{~N} / \mathrm{m}$, tip radius $\sim 35 \mathrm{~nm}$ ) in $14 \mathrm{ml}$ ethanol containing $10 \mathrm{mM}$ (11-mercaptoundecyl)-N,N,N-trimethylammonium bromide $\left(\mathrm{HS}\left(\mathrm{CH}_{2}\right)_{11} \mathrm{~N}\left(\mathrm{CH}_{3}\right)_{3} \mathrm{Br}\right)$ for $48 \mathrm{~h}$, rinsed with ethanol and air-dried in a chemical hood.

\section{AFM imaging, force measurement \& analysis}

All AFM experiments were performed at room temperature using a Bruker Dimension ICON AFM with ScanAsyst (Bruker). AFM topographic images were obtained using ScanAsyst in liquid mode with a ScanAsyst-Fluid+ silicon nitride AFM probe (spring constant $\sim 0.7 \mathrm{~N} / \mathrm{m}$, tip radius $\sim 2 \mathrm{~nm}$ ) or an NT-MDT CSG30 AFM probe (spring constant $\sim 0.6 \mathrm{~N} / \mathrm{m}$, tip radius $\sim 6 \mathrm{~nm}$ ). All topographic images were obtained in PBS. Images containing nanoparticles were flattened, cleaned, and plane fitted to remove the background.

AFM force measurements were performed in PeakForce QNM mode or contact mode in liquid. The modified AFM probe spring constant was calibrated before the force measurement experiment by measuring the thermal noise of the free cantilever in liquid [16]. Over 500 force-distance (F-D) curves were recorded with at least three separate combinations of probe/virus samples. All F-D curve measurements between modified probes and viral particle surfaces were collected in liquid conditions with PBS (for hydrophobicity measurement) or PB (for surface charge measurement). The control experiments were carried out under the same conditions. Data analysis was performed with the Bruker Nanoscope Analysis software.

\section{Results \& discussion}

To characterize virus surface chemistry by the single-particle CFM method, the key steps were functionalization of AFM probes with the chemical functional group of interest (Figure 1A) and immobilization of virus particles on a surface (Figure 1B).

\section{Virus \& virus surrogate immobilization}

Virus AFM experiments are commonly done by deposition of the virus to a surface [26], and characterization is by nanoindentation [16,27]. The goal of nanoindentation is to measure the force needed to break open a virus capsid by pushing on it. However, in our work, we are pulling on the virus rather than pushing on it. Physical adsorption to immobilize viruses is simple, but the capsid proteins might deform during adsorption [26]. It was a concern that the virus may have a stronger bond to the AFM probe than to the surface, resulting in a misleading rupture force being measured. The antibody capture and covalent binding methods provide strong bonds between the virus and the surface $[28,29]$. The antibody binding method is virus-specific, but the antibody is expensive and has limited chemical stability; 


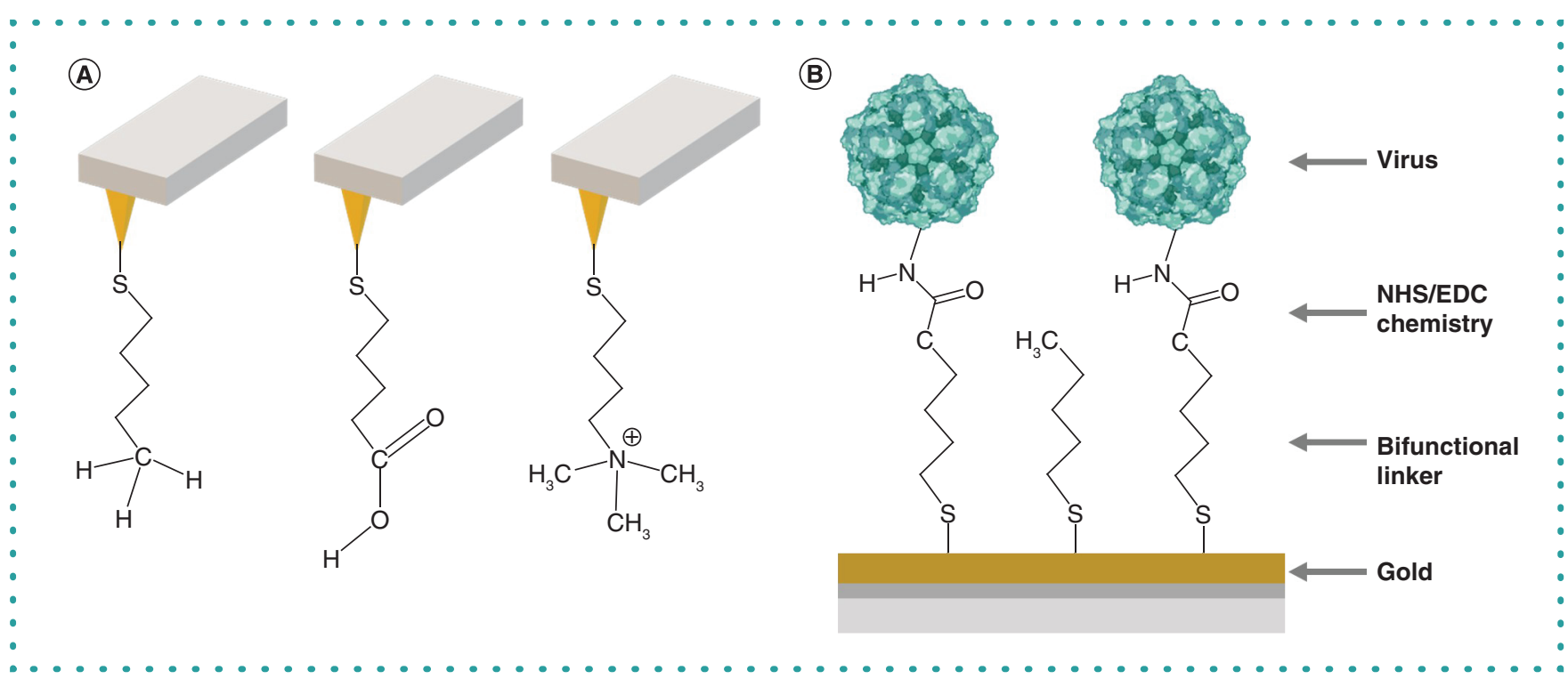

Figure 1. Cartoon of atomic force microscope probe surface modification and virus attachment on a gold surface. (A) Atomic force microscope probes were functionalized with either a hydrophobic methyl group, a negatively charged carboxyl acid group or a positively charged quaternary amine group. (B) Viral particles were immobilized with NHS/EDC chemistry. Not all carbons in the linker are represented. Virus image was created in BioRender.

EDC: 1-ethyl-3-(3-dimethylaminopropyl) carbodiimide hydrochloride; NHS: N-hydroxysulfosuccinimide.

thus we chose the covalent binding method. By covalently bonding the virus to the surface, we would be assured that the AFM force experiment was measuring chemical interaction between the virus and the AFM probe, and not between the virus and the solid surface.

To covalently bond the virus to the surface, a bifunctional linker containing a thiol functional group was chemisorbed onto the Au surface [30]. The linker contained a carbon chain that can form a self-assembled monolayer (SAM) on the Au-coated slide (Figure 1B). The functional group $\mathrm{COOH}$ was chosen because it covalently attaches to lysines on the virus surface using EDC and NHS chemistry [31,32]. The surface was a mixture of $\mathrm{COOH}$-capped and $\mathrm{CH}_{3}$-capped compounds to control the density of the $\mathrm{COOH}$ bifunctional linker, which determines the number of immobilized virus particles.

To test the covalent immobilization chemistry, $\mathrm{NH}_{2}$-NPs were used as a virus surrogate and attached to the $\mathrm{COOH}$-modified surface. The natural particle size of $10-15 \mathrm{~nm}$ was detected for $\mathrm{NH}_{2}-\mathrm{NPs}$ in topographic images (Figure $2 \mathrm{~A}-\mathrm{C}$ ), confirming the utility of the immobilization chemistry. To determine the optimal density of particles attached to the surface, various ratios of $\mathrm{COOH}$-capped and $\mathrm{CH}_{3}$-capped thiol linkers (9:1, 1:1 and 1:9) were tested. A ratio of 9:1 $\mathrm{COOH} / \mathrm{CH}_{3}$ caused a high density of NPs and resulted in aggregated NPs that could not be individually distinguished, as shown in Figure 2A. The best ratio of $\mathrm{COOH}$-and $\mathrm{CH}_{3}$-capped thiols was 1:1 (Figure 2B), and this condition was used for further experiments. At a ratio of 1:9, too few NPs attached to the surface (Figure $2 \mathrm{C}$ ), making locating the virus difficult. Control surfaces were measured to determine the roughness of the surface at different stages of functionalization. Figure 2D shows that the hydrophobic functional group $\mathrm{SAM}-\mathrm{CH}_{3}$ modified surface had a surface roughness of $\sim 3 \mathrm{~nm}$, the same as was found for the bare Au surface control (Figure 2E) and the NHS-EDC modified surface (Figure 2F).

The successful immobilization of virus particles was demonstrated using PPV and BVDV through topographic images and corresponding height analysis (Figure 3A \& B). The PPV had a measured size of $23 \pm 3 \mathrm{~nm}$, which falls within the reported size range of PPV of 18-26 nm [33]. In addition, Figure 3B shows that BVDV has a size of $46 \pm 8 \mathrm{~nm}$, consistent with the reported size of BVDV [34]. The height analysis results also indicate that our covalent virus-immobilizing method can keep a natural form of the virus without deformation or disassembly. We also used physical adsorption to immobilize virus particles by depositing them onto the Au surface without covalently binding (Figure $3 C \& D$ ). The measured sizes for both PPV and BVDV were smaller than the sizes reported in the literature, indicating that deformation of the virus particles had occurred.

\section{AFM probe modification}

The chemical group that functionalizes the AFM probe determines what viral surface chemistry can be explored. Commercially available AFM tips are typically made of silicon nitride, which can form a silanol ( $\mathrm{SiOH}$ ) surface layer on the AFM tip in air. Common methods for functionalization of AFM tips are silanization between the silanol groups and a silane coupling agent such as R-(CH $)_{n}-\mathrm{Si}-\left(\mathrm{OC}_{2} \mathrm{H}_{5}\right)_{3}$ (where R represents any chemical group of interest) [35,36], and esterification between the silanol groups and a hydroxyl-terminated agent $\mathrm{R}-\left(\mathrm{CH}_{2}\right)_{\mathrm{n}}-\mathrm{OH}[37,38]$. Both silanization and esterification require heat treatment of the AFM tip to $>100^{\circ} \mathrm{C}$ [35-38]. Another method is to coat the AFM tip with Au and adsorb an alkanethiol agent $\mathrm{R}-\left(\mathrm{CH}_{2}\right)_{\mathrm{n}}-\mathrm{SH}$ onto the AFM tip $[18,21,39]$. The advantages of thiol attachment 

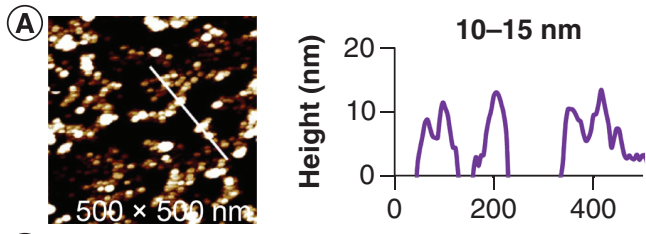

(B)
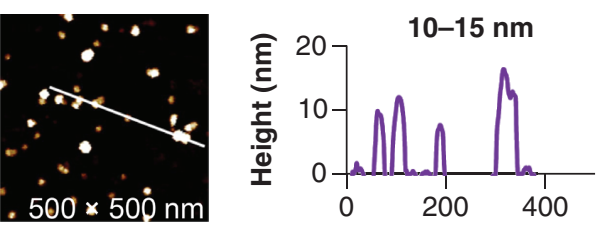

(C)
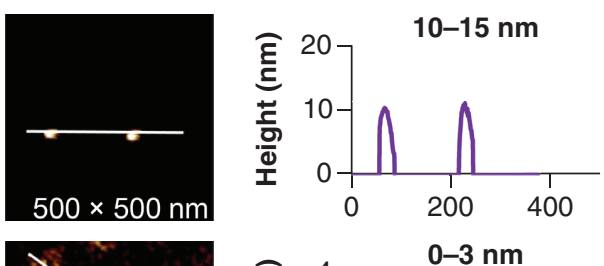

(D)
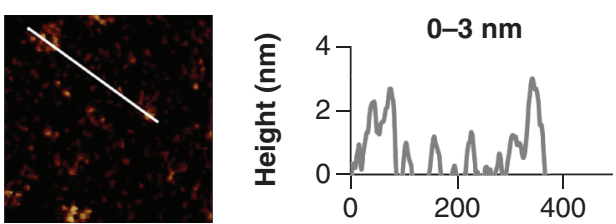

(E)
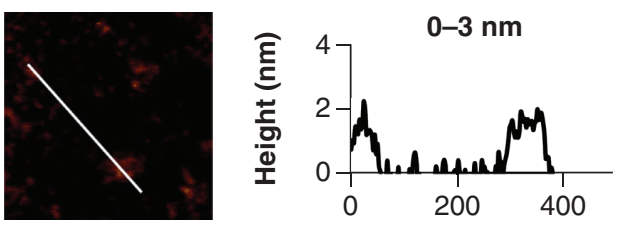

(F)
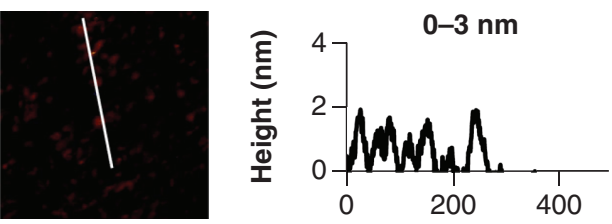

Horizontal distance (nm)

Figure 2. Topographic images and corresponding height analysis of virus surrogate primary amine-functionalized silica nanoparticles with different ratios of $\mathrm{COOH}$ and $\mathrm{CH}_{3}$-capped thiol linkers and controls. Silica nanoparticles were imaged after immobilization with (A) 9:1, (B) 1:1 and (C) 1:9 ratios of $\mathrm{COOH}$ to $\mathrm{CH}_{3}$. Control surfaces were: (D) $\mathrm{CH}_{3}$-modified surface, (E) bare gold surface and (F) NHS-EDC surface.

EDC: 1-ethyl-3-(3-dimethylaminopropyl) carbodiimide hydrochloride; $\mathrm{NH}_{2}$-NP: Primary amine-functionalized silica nanoparticle; $\mathrm{NHS}$ :

$\mathrm{N}$-hydroxysulfosuccinimide.

(B) Reproduced with permission from [9].

chemistry for tip modification are that thiol attachment can be performed at room temperature with a low concentration $(\sim 1 \mathrm{mM})$ of alkanethiol agent $[18,21,39]$, and that commercially available alkanethiol agents are terminated in a variety of chemistries. We chose the thiol attachment method for the AFM probe modification (Figure 1A).

To measure small molecular binding interactions, a very soft, Au-coated Bruker AC-40 AFM probe (tip radius $\sim 10 \mathrm{~nm}$ ) was used. To functionalize the tip with a $\mathrm{CH}_{3}$ functional group, a coating condition of $1 \mathrm{mM} \mathrm{HS}\left(\mathrm{CH}_{2}\right)_{11} \mathrm{CH}_{3}$ in ethanol for $12 \mathrm{~h}$ [39] was used. To confirm the probe functionalization, the force was measured between the coated probe and a $\mathrm{CH}_{3}$-modified control surface in PBS at pH 7.2. However, no adhesion force could be detected, as shown in Table 1. The coating concentration was increased to $2 \mathrm{mM}$ for $12 \mathrm{~h}$, but still no adhesion force was measured. Next, the coating concentration was increased to $4 \mathrm{mM}$ and the coating time to $24 \mathrm{~h}$. These changes resulted in strong adhesion forces with a mean value of $1734 \mathrm{pN}$, as shown in Table 1 and Figure 4A. The coating condition reported in the literature did not work in our experiment, likely due to the tiny AFM tips used in our work as compared with the larger tip area used in the previous work [39]. The small available area for coating limited the efficiency of $\mathrm{CH}_{3}$ group binding. 
(A)
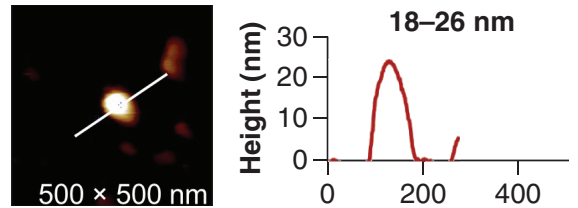

(C)

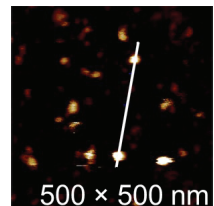

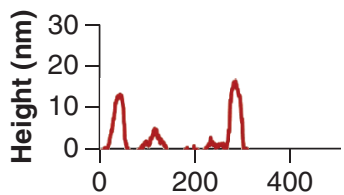

Horizontal distance $(\mathrm{nm})$
(B)
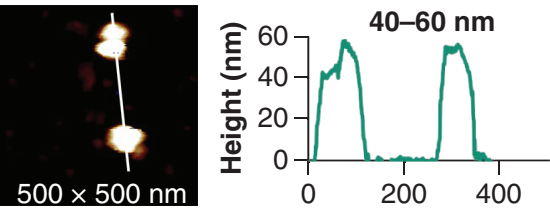

(D)
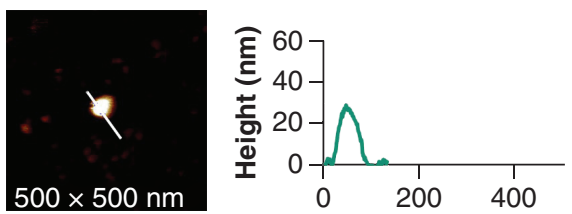

Horizontal distance $(\mathrm{nm})$

Figure 3. Topographic images and corresponding height analysis of viruses. (A) Porcine parvovirus covalently bound to gold. (B) Bovine viral diarrhea virus covalently bound to gold. (C) Porcine parvovirus deposited on gold. (D) Bovine viral diarrhea virus deposited on gold.

\section{Table 1. Adhesion force at different atomic force microscope probe functionalization conditions.}

\begin{tabular}{|c|c|c|c|c|}
\hline \multirow[t]{3}{*}{ Concentration (mM) } & \multicolumn{4}{|c|}{ Chemistry } \\
\hline & \multicolumn{2}{|c|}{$\mathrm{HS}\left(\mathrm{CH}_{2}\right)_{11} \mathrm{CH}_{3}$} & \multicolumn{2}{|c|}{$\mathrm{HS}\left(\mathrm{CH}_{2}\right)_{11} \mathrm{~N}\left(\mathrm{CH}_{3}\right)_{3} \mathrm{Br}$} \\
\hline & $12 \mathrm{~h}$ & $24 \mathrm{~h}$ & $24 \mathrm{~h}$ & $48 \mathrm{~h}$ \\
\hline 1 & $0 \mathrm{pN}$ & NA & NA & NA \\
\hline 2 & $0 \mathrm{pN}$ & NA & NA & NA \\
\hline 4 & NA & $1734 \mathrm{pN}$ & $0 \mathrm{pN}$ & NA \\
\hline 10 & NA & NA & NA & $165 \mathrm{pN}$ \\
\hline
\end{tabular}

All mean forces $>0$ were calculated based on the adhesion forces from 500 recorded F-D curves with at least three separate combinations of probe/control samples. Null adhesion force was based on $50 \mathrm{~F}-\mathrm{D}$ curves with one combination of probe/control sample. NA: Condition not tested.

(A)

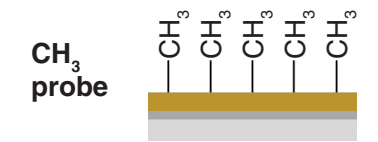

(B)

COOprobe<smiles>NC1CC(N)C(N)C1N</smiles>

(C)

$\mathrm{NR}_{4}^{+}$ probe

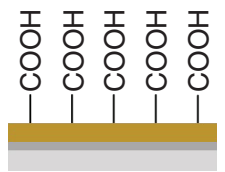

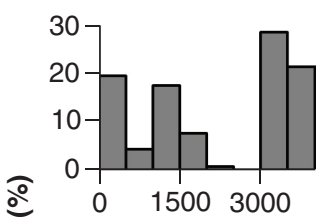
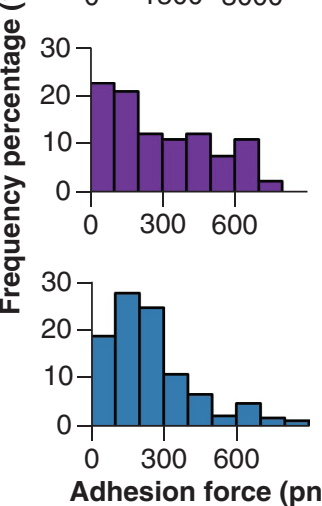
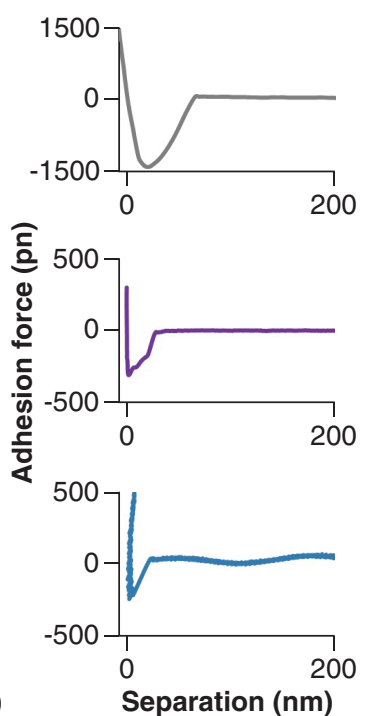

Figure 4. Probe functionalization confirmation. Adhesion histograms and representative F-D curves (retraction only) of positive control surface with a $\mathrm{CH}_{3}$-terminated, $\mathrm{COOH}$-terminated or $\mathrm{NR}_{4}{ }^{+}$-terminated probe. (A) $\mathrm{CH}_{3}$-terminated probe with a $\mathrm{CH}_{3}$-modified surface, measured in phosphate-buffered saline at $\mathrm{pH}$ 7.2. (B) $\mathrm{COO}^{-}$-terminated probe with a $\mathrm{NH}_{2}$-NPs modified surface, measured in 20 mM phosphate buffer at pH 7.0. (C) $\mathrm{NR}_{4}{ }^{+}$-terminated probe with a $\mathrm{COOH}$-modified surface, measured in $20 \mathrm{mM}$ phosphate buffer at pH 7.0. Multiple $(n=500)$ F-D curves were recorded over areas of 500 $\times 500 \mathrm{~nm}$ 


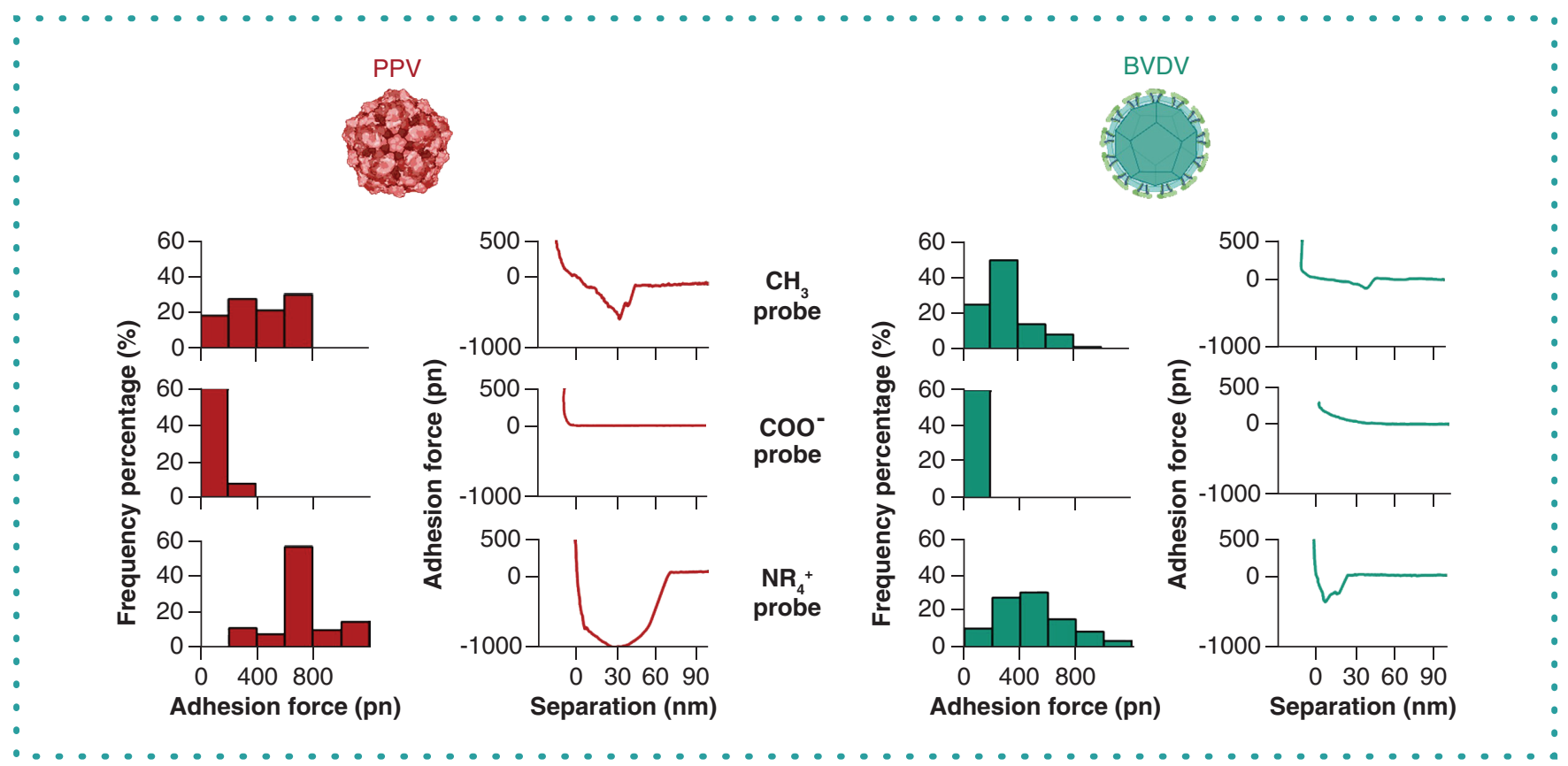

Figure 5. Adhesion histograms and representative force-distance curves (retraction only) of the virus. The images show measurements with a $\mathrm{CH}_{3}$-terminated, $\mathrm{COO}^{-}$-terminated or $\mathrm{NR}_{4}{ }^{+}$-terminated probe, recorded in phosphate-buffered saline at $\mathrm{pH} 7.2$ (for hydrophobicity measurement) or $20 \mathrm{mM}$ phosphate buffer at $\mathrm{pH} 7.0$ (for surface charge measurement). Multiple $(\mathrm{n}=500)$ F-D curves were recorded over $500 \mathrm{~nm} \times 500 \mathrm{~nm}$ areas. Virus images were created in BioRender.

BVDV: Bovine viral diarrhea virus; PPV: Porcine parvovirus.

To confirm the probe modification for the surface charge study, the negatively charged carboxyl (COO)-terminated probe at coating condition with $4 \mathrm{mM} \mathrm{HS}\left(\mathrm{CH}_{2}\right)_{11} \mathrm{COOH}$ in ethanol for $24 \mathrm{~h}$ was tested with positively charged $\mathrm{NH}_{2}-\mathrm{NPs}$ in $\mathrm{PB}$ at $\mathrm{pH}$ 7.0. Strong adhesion forces were measured, with a mean value of $210 \mathrm{pN}$ (Figure 4B). No adhesion forces could be detected on the $\mathrm{COO}^{-}$-modified control surface at $\mathrm{pH} 7.0$ (data not shown).

The positively charged quaternary amine $\left(\mathrm{NR}_{4}^{+}\right)$-terminated probe was tested with a $\mathrm{COO}^{-}$-modified control surface in $\mathrm{PB}$ at $\mathrm{pH}$ 7.0. To functionalize with the $\mathrm{NR}_{4}{ }^{+}$, the same coating condition with $4 \mathrm{mM} \mathrm{HS}\left(\mathrm{CH}_{2}\right)_{11} \mathrm{COOH}$ in ethanol for $24 \mathrm{~h}$ was used with the AC-40 AFM probe. No adhesion forces could be detected (Table 1). It was possible that the probe coating might be hindered by the small available area of the AC-40 probe, so another soft NT-MDT CSG10/Au AFM probe (tip radius $\sim 35 \mathrm{~nm}$ ) was coated following the same coating concentration with $\mathrm{HS}\left(\mathrm{CH}_{2}\right)_{11} \mathrm{~N}\left(\mathrm{CH}_{3}\right)_{3} \mathrm{Br}$ in ethanol. On average, one out of ten probes tested was successfully coated with the $\mathrm{NR}_{4}{ }^{+}$. To improve the binding efficiency, a condition of $10 \mathrm{mM}$ for $48 \mathrm{~h}$ was tested to coat the CSG10/Au probe. Strong adhesion forces were observed (Figure $4 \mathrm{C}$ ), with a mean force of $165 \mathrm{pN}$. No adhesion forces could be detected on the positively charged $\mathrm{NH}_{2}-\mathrm{NPs}$ control surface (data not shown). It is likely that a high coating concentration and long coating time were needed due to the repulsion of the positively charged quaternary amine.

\section{Virus surface chemistry characterization}

Non-enveloped PPV and enveloped BVDV were selected to explore virus surface chemistry with CFM; some of their properties can be found in Supplementary Table 1. CFM was able to quantify hydrophobic interactions between a $\mathrm{CH}_{3}$-modified AFM probe and an immobilized viral particle, enabling a direct comparison of hydrophobicity between different viruses. For the hydrophobicity study, CFM force measurements were performed in PBS at pH 7.2. All the histograms are summarized in Figure 5, and the adhesion of PPV and BVDV to the hydrophobic $\mathrm{CH}_{3}$ probe are shown in the top graphs. The mean forces were calculated based on the adhesion forces from 500 recorded F-D curves (Table 2). PPV showed a higher adhesion force than BVDV, indicating that PPV is more hydrophobic than BVDV, probably because the enveloped BVDV contains glycolipids with hydrophilic heads [40]. Thus PPV might prefer to adsorb to more hydrophobic surfaces than BVDV. Due to the different tip radii used, the magnitude of the forces for the $\mathrm{NR}_{4}{ }^{+}$probe cannot be directly compared with the other forces for the same virus.

Most viruses carry a negative charge under physiological conditions due to the viral isoelectric points typically being below 7 [11]. AFM probes terminated with $\mathrm{COO}^{-}$groups and $\mathrm{NR}_{4}{ }^{+}$groups were used to measure the surface charge of PPV and BVDV. To explore the electrostatic interactions of the viral surface, viruses were studied in a low-ionic-strength buffer because high salt concentration will shield electrostatic interactions. The electrostatic attractions between the surface of viruses and charged chemically modified AFM probes were measured at $\mathrm{pH} 7.0$. 


\section{Table 2. Mean force measured during chemical force microscopy.}

\begin{tabular}{llr}
\hline Chemistry & & Virus \\
& PPV & BVDV \\
$\mathrm{CH}_{3}$ & $272 \pm 205 \mathrm{pN}^{\dagger}$ & $118 \pm 188 \mathrm{pN}^{\dagger}$ \\
$\mathrm{COO}^{-}$ & $2 \pm 5 \mathrm{pN}$ & $0 \pm 1 \mathrm{pN}^{-}$ \\
$\mathrm{NR}_{4}{ }^{+}$ & $570 \pm 278 \mathrm{pN}^{\dagger}$ & $304 \pm 250 \mathrm{pN}^{\dagger}$
\end{tabular}

Measurements were made at a pH of 7.2 for the methyl probe and 7.0 for the charged probes. The tip radius for the $\mathrm{CH}_{3}$ probe and the $\mathrm{COO}^{-}$probe was $\sim 10$ nm and the radius of the $\mathrm{NR}_{4}+$ probe was $\sim 35 \mathrm{~nm}$.

$\dagger$ The difference between the measurement of PPV and BVDV had a p-value of $<0.01$ using the Student's $t$-test.

BVDV: Bovine viral diarrhea virus; PPV: Porcine parvovirus.

The middle graphs in Figure 5 show PPV adhesion to a negatively charged CO0- probe. Almost no adhesion was observed at pH 7.0. In the complementary experiment with the positively charged $\mathrm{NR}_{4}{ }^{+}$modified AFM probe, strong adhesion was observed for PPV at pH 7.0 (bottom of Figure 5 \& Table 2). Similar force measurements were performed for the enveloped virus BVDV (Figure 5), and similar adhesion phenomena were observed for its surface charge. However, the mean electrostatic force collected for BVDV was smaller than that of PPV. Even though the values for mean adhesion force had a high error (Table 2), the differences between the positive charge adhesion for each virus were statistically significant, and so was the difference in the hydrophobic adhesion.

\section{Future perspective}

There is no universal surface chemistry measurement for viruses, making it difficult to compare published results. CFM can detect the surface chemistry of viral capsids at a single-particle level and could be established as a baseline comparison of the surface chemistry between different types of viruses. The heterogeneity of virus populations could be studied with CFM and such study would give us extended knowledge of how population-level dynamics change viral infectivity and other properties. More study is needed of the viral proteins to understand the hydrophobicity and charge differences between viruses.

\section{Executive summary}

- Chemical force microscopy is a single-particle method to measure virus surface chemistry.

- Covalent virus immobilization methods can retain a natural form of the virus without deformation or disassembly.

- The atomic force microscope probe functionalizing method of thiol attachment to a gold-coated tip allows the attachment of many chemical functional groups of interest.

- A non-enveloped and enveloped virus were compared for charge and hydrophobicity.

\section{Supplementary data}

To view the supplementary data that accompany this paper please visit the journal website at: www.futurescience.com/doi/suppl/10.2144/btn-2020-0085

\section{Author contributions}

Under the supervision of $\mathrm{C}$ Heldt, $\mathrm{X}$ Mi performed all the experimental work, collected and analyzed all the data, drew all the figures and wrote the manuscript. $\mathrm{C}$ Heldt also made a significant contribution to edit the manuscript.

\section{Acknowledgments}

The authors are grateful to F Long for the AFM training and technical support, and C Kendrick for his assistance and instruction on the microfabrication facility.

\section{Financial \& competing interests disclosure}

The authors thank EMD Millipore for the gift of chemicals used in this work. Financial support was received from NSF (CAREER-1451959), the Department of Chemical Engineering at Michigan Tech, and the James and Lorna Mack Chair in Bioengineering. The authors have no other relevant affiliations or financial involvement with any organization or entity with a financial interest in or financial conflict with the subject matter or materials discussed in the manuscript apart from those disclosed.

No writing assistance was utilized in the production of this manuscript.

\section{Open access}

This work is licensed under the Attribution-NonCommercial-NoDerivatives 4.0 Unported License. To view a copy of this license, visit http: //creativecommons.org/licenses/by-nc-nd/4.0/ 


\section{References}

Papers of special note have been highlighted as: $\bullet$ of interest

1 Dika C, Duval JFL, Francius G, Perrin A, Gantzer C. Isoelectric point is an inadequate descriptor of MS2, Phi X 174 and PRD1 phages adhesion on abiotic surfaces. J. Colloid Interface Sci. 446, 327-334 (2015).

2 Meder F, Wehling J, Fink A et al. The role of surface functionalization of colloidal alumina particles on their controlled interactions with viruses. Biomaterials 34(17), 4203-4213 (2013).

3 Chung JW, Breulmann M, Clemens A, Fuhner C, Foppen JW, Lens PNL. Simultaneous removal of rotavirus and adenovirus from artificial ground water using hydrochar derived from swine feces. J. Water Health 14(5), 754-767 (2016).

4 Mi X, Heldt CL. Adsorption of a non-enveloped mammalian virus to functionalized nanofibers. Colloids Surf. B 121, 319-324 (2014).

5 Mi X, Vijayaragavan KS, Heldt CL. Virus adsorption of water-stable quaternized chitosan nanofibers. Carbohydr. Res. 387, 24-29 (2014).

6 Joshi PU, Turpeinen DG, Weiss M, Escalante-Corbin G, Schroeder M, Heldt CL. Tie line framework to optimize non-enveloped virus recovery in aqueous two-phase systems. J. Chromatogr. B 1126-1127, 121744 (2019)

- A polyethylene glycol-citrate system to purify viruses based on the difference in the surface hydrophobicity between the virus and proteins. Virus recovery showed dependence on its surface charge.

7 Van Doremalen N, Bushmaker T, Morris DH et al. Aerosol and surface stability of SARS-CoV-2 as compared with SARS-CoV-1. N. Engl. J. Med. 382(16), 1564-1567 (2020).

8 Heldt CL, Zahid A, Vijayaragavan KS, Mi X. Experimental and computational surface hydrophobicity analysis of a non-enveloped virus and proteins. Colloids Surf. B 153, 77-84 (2017).

- A nonenveloped porcine parvovirus was demonstrated to be more hydrophobic than a panel of model proteins experimentally and computationally.

9 Mi X, Bromley EK, Joshi PU, Long F, Heldt CL. Virus isoelectric point determination using single-particle chemical force microscopy. Langmuir 36(1), 370-378 (2020).

- Chemical force microscopy with a charged group-modified atomic force microscope probe to determine the isoelectric points of porcine parvovirus and bovine viral diarrhea virus.

10 Johnson SA, Walsh A, Brown MR et al. The step-wise framework to design a chromatography-based hydrophobicity assay for viral particles. J. Chromatogr. B 1061, 430-437 (2017).

11 Michen B, Graule T. Isoelectric points of viruses. J. Appl. Microbiol. 109(2), 388-397 (2010).

- Reviewed the pls of viruses as measured by isoelectric focusing and electrophoretic mobility.

12 Samandoulgou I, Fliss I, Jean J. Zeta potential and aggregation of virus-like particle of human norovirus and feline calicivirus under different physicochemical conditions. Food Environ. Virol. 7(3), 249-260 (2015).

13 Braun M, Gebauer W, Krczal G, Ziegler C, Muller-Renno C, Boonrod K. A simple method to estimate the isoelectric point of modified tomato bushy stunt virus (TBSV) particles. Electrophoresis 38(21), 2771-2776 (2017).

14 Shi H, Tarabara VV. Charge, size distribution and hydrophobicity of viruses: effect of propagation and purification methods. J. Virol. Methods 256, 123-132 (2018).

15 Leuchs B, Frehtman V, Riese M, Muller M, Rommelaere J. A novel scalable, robust downstream process for oncolytic rat parvovirus: isoelectric point-based elimination of empty particles. Appl. Microbiol. Biotechnol. 101(8), 3143-3152 (2017).

16 Santos NC, Carvalho FA. Atomic Force Microscopy: Methods and Protocols. Springer, NY, USA (2019).

17 Kámán J. Young's modulus and energy dissipation determination methods by AFM, with particular reference to a chalcogenide thin film. Period. Polytech. Elec. Eng. Comp. Sci. 59(1), 18-25 (2015).

18 Viljoen A, Viela F, Kremer L, Dufrêne YF. Fast chemical force microscopy demonstrates that glycopeptidolipids define nanodomains of varying hydrophobicity on mycobacteria. Nanoscale Horiz. 5, 944-953 (2020).

- Chemical force microscopy with a hydrophobic group-modified atomic force microscope tip is a powerful tool to quantitatively map surface hydrophobicity of $M$. abscessus.

19 El-Kirat-Chatel S, Beaussart A, Derclaye S et al. Force nanoscopy of hydrophobic interactions in the fungal pathogen Candida glabrata. ACS Nano 9(2), 1648-1655 (2015).

20 Guo SF, Zhu XY, Janczewski D et al. Measuring protein isoelectric points by AFM-based force spectroscopy using trace amounts of sample. Nat. Nanotechnol. 11(9), 817-823 (2016).

21 Ahimou F, Denis FA, Touhami A, Dufrene YF. Probing microbial cell surface charges by atomic force microscopy. Langmuir 18(25), 9937-9941 (2002).

- Reviewed basic and advanced atomic force microscope-related approaches to characterize biointerfaces including tissues, cells, membranes, proteins, nucleic acids and functional materials.

22 Alsteens D, Gaub HE, Newton R, Pfreundschuh M, Gerber C, Muller DJ. Atomic force microscopy-based characterization and design of biointerfaces. Nat. Rev. Mater. 2(5), 17008 (2017).

23 Sullan RMA, Churnside AB, Nguyen DM, Bull MS, Perkins TT. Atomic force microscopy with sub-picoNewton force stability for biological applications. Methods 60(2), 131-141 (2013).

24 Mi X, Lucier EM, Turpeinen DG, Yeo ELL, Kah JCY, Heldt CL. Mannitol-induced gold nanoparticle aggregation for the ligand-free detection of viral particles. Analyst 144(18), 5486-5496 (2019).

25 Meng H, Forooshani PK, Joshi PU et al. Biomimetic recyclable microgels for on-demand generation of hydrogen peroxide and antipathogenic application. Acta Biomater. 83, 109-118 (2019).

26 Zeng C, Moller-Tank S, Asokan A, Dragnea B. Probing the link among genomic cargo, contact mechanics, and nanoindentation in recombinant adeno-associated virus 2 . J. Phys. Chem. B 121(8), 1843-1853 (2017).

27 De Pablo PJ. Atomic force microscopy of virus shells. Semin. Cell Dev. Biol. 73, 199-208 (2018)

28 Hodges JA, Saffarian S. Sample preparation for single virion atomic force microscopy and super-resolution fluorescence imaging. J. Vis. Exp. 83, 51366 (2014).

29 Meillan M, Ramin MA, Buffeteau T et al. Self-assembled monolayer for AFM measurements of tobacco mosaic virus (TMV) at the atomic level. RSC Adv. 4(23), 11927-11930 (2014).

30 Pensa E, Cortes E, Corthey G et al. The chemistry of the sulfur-gold interface: in search of a unified model. Acc. Chem. Res. 45(8), 1183-1192 (2012).

31 Khaldi K, Sam S, Lounas A, Yaddaden C, Gabouze NE. Comparative investigation of two methods for acetylcholinesterase enzyme immobilization on modified porous silicon. Appl. Surf. Sci. 421, 148-154 (2017).

32 Bearinger JP, Dugan LC, Wu LG, Hill H, Christian AT, Hubbell JA. Chemical tethering of motile bacteria to silicon surfaces. BioTechniques 46(3), 209-216 (2009).

33 Norkin LC. Virology: Molecular Biology and Pathogenesis. ASM press, Washington DC, USA (2010).

34 Kim IS, Choi YW, Lee SR. Optimization and validation of a virus filtration process for efficient removal of viruses from urokinase solution prepared from human urine. J. Microbiol. Biotechnol. 14(1), 140-147 (2004)

35 Ratto TV, Rudd RE, Langry KC, Balhorn RL, Mcelfresh MW. Nonlinearly additive forces in multivalent ligand binding to a single protein revealed with force spectroscopy. Langmuir 22(4), 1749-1757 (2006)

36 Ratto TV, Langry KC, Rudd RE, Balhorn RL, Allen MJ, Mcelfresh MW. Force spectroscopy of the double-tethered concanavalin - a mannose bond. Biophys. J. 86(4), 2430-2437 (2004).

37 Blanchette CD, Loui A, Ratto TV. Tip functionalization: applications to chemical force spectroscopy. In: Handbook of Molecular Force Spectroscopy. Springer, MA, USA (2008).185-203

38 Riener CK, Stroh CM, Ebner A et al. Simple test system for single molecule recognition force microscopy. Anal. Chim. Acta 479(1), 59-75 (2003).

39 Alsteens D, Dupres V, Yunus S, Latge JP, Heinisch JJ, Dufrene YF. High-resolution imaging of chemical and biological sites on living cells using peak force tapping atomic force microscopy. Langmuir 28(49), 16738-16744 (2012).

40 Lorizate M, Krausslich HG. Role of lipids in virus replication. Cold Spring Harbor Perspect. Biol. 3(10), a004820 (2011). 